\title{
CAN WE USE SECOND LIFE FOR LANGUAGE LEARNING AND INSTRUCTION?
}

\author{
Yavuz Samur
}

\begin{abstract}
Over the last few years there has been an increased interest in Multi-User Virtual Environments (MUVEs), or virtual worlds, by instructional designers and developers. One of these MUVEs is a very well known world, Second Life (SL). There are many instructional activities taking place in Second Life and language learning, English-as-a-foreign-language (EFL) learning is just one of them. Gartner Inc. (2007) says that 80 percent of active internet users will have a "Second Life" in the virtual world by the end of 2011. In this paper, the researches and use of SL in language instruction is examined and some suggestions are offered to both instructors and designers on how they can leverage of SL especially in higher education settings.
\end{abstract}

Keywords: Virtual environment, language learning (EFL), higher education

\section{DIL ÖĞRENME ARACI OLARAK İKINCİ YAŞAM (YDÖ)}

$$
\ddot{O}_{z e t}
$$

Son zamanlarda çok kullanıcılı sanal ortamlara, diğer bir deyişle sanal dünyalara karşı öğretim tasarımcıları ve eğitmenler tarafindan giderek artan bir ilgi olduğu çok açıktır. Bu ortamlardan biri de, herkes tarafindan bilinen İkinci Yaşam (Second Life 'tır). İkinci Yaşam'da birçok öğretimsel aktiviteler mevcuttur ve dil ögrrenimi, özellikle yabancı dil ögrenimi olarak (YDÖ) İngilizce ögrenme bunlardan sadece biridir. Gartner Inc. (2007) 2011 yllının sonuna kadar aktif olarak internet kullanan kullanıcıların \%80'inin Ikkinci Yaşam da yer alacă̆ını belirtmiştir. Bu makalede ise İkinci Yaşam ile ilgili araştırmalar ve İkinci Yaşam ’ın dil öğretiminde kullanılması incelenmiş ve ögrretim tasarımcılarına ve ĕgitmenlere İkinci Yaşam'dan özellikle yüksek ögretimde nasıl faydalanabilecekleri hakkında bazı öneriler getirilmiştir.

Anahtar sözcükler: Sanal ortam, dil ögrenme (YDÖ), yüksek eğitim 


\section{Introduction}

Gartner Inc. (2007) says 80 percent of active internet users will have a "Second Life (SL)" in the virtual world by the end of 2011. What we, as instructional designers and educators, also expect is that there is going to be more research on effects of 3$\mathrm{D}$ virtual worlds in terms of learning and instruction. Second Life has been used in variety of courses in educational setting. Therefore this paper presents a literature review, ideas, and suggestions on using Second Life as a language learning and practice tool for higher education students learning English as a foreign language. The purpose of the study is to answer these two questions below:

a. How are educators, practitioners and learners using SL for the purpose of language learning and instruction?

b. How can SL be utilized / designed better for language learning/learners?

This paper will describe how MUVEs, primarily focusing on SL, can affect EFL programs and learners. Therefore students who learn English as a foreign language in higher education settings and who are using SL are going to be the main target of this review.

It is examined that the researches and use of SL in language instruction and offer suggestions to both instructors and designers on how they can leverage of SL especially in higher education settings. In addition to its advantages, the disadvantages are going to be discussed in this paper as well in order to approach this virtual world from an objective angle and give some really experience based ideas to the instructors and designers. Virtual worlds especially Second Life is first briefly summarized and then how SL can be used for language learning. Next the current situation of using SL in language learning and as a tool for practice with other language learners is examined. Then some advantages and drawbacks are mentioned. The paper is going to be concluded with some useful recommendations to the instructors and designers of instructional application of SL for effective teaching, learning and practice.

\section{Virtual environments - Second Life}

Over the last few years there has been an increased interest in the use of Multi-User Virtual Environments (MUVEs), or virtual worlds, by instructional designers and developers. Virtual worlds allow users to interact with one another with a greater sense of presence than in audio, video or web conferencing. The sense of presence inherent in virtual worlds appears to aid engagement and collaboration, and has been identified as having key benefits for education and training purposes (de Freitas \& Veletsianos, 2010). To date, the one predominant MUVE environment that has taken most of the focus of educational research is Second Life (SL). Higher 
education institutes are beginning to move their online education classes into Second Life. Over a hundred educational institutions offer meeting space and hold classes in SL (Atkinson, 2008). As of January 2010 there are more than 18 million users registered in SL with more than 60,000 individuals logged in at the same time (Linden Research, 2010).

The literature examined tells us that the general characteristics of virtual worlds and their potential benefits for teaching and learning have collectively yielded a long list of positive capabilities. On the other hand there are also some negative features effecting the learning environment as well. These are going to be discussed in this paper as well. Kalyuga (2007) found that virtual worlds are highly interactive in that they provide dynamic feedback, learner experimentation, real-time personalized task selection, and exploration. Open virtual worlds like SL provide an environment supportive of learning activities such as experimentation, exploration, task selection, creation, and dynamic feedback; and this supportive platform suggests that virtual worlds are likely to accommodate project-based experiential learning (Jarmon, Traphagan, Mayrath \& Trivedi, 2009).

Second Life looks encouraging to many educators in higher education because of its features and advantages. People can explore, meet with other residents, socialize, participate in individual and group activities, and travel throughout the world in SL. Now that Web 2.0 tools are more easily integrated within Second Life, designers have the opportunity to enhance the learning environment with wikis, blogs and calendars in order to support it with asynchronous tools as well. Virtual worlds, through their use of avatars, also provide the potential to enhance reflection as a vehicle for learning (Twining, 2009). It has what Graham Stanley, the project manager for the British Council's island in Second Life, calls "a sense of place" which "makes learning, and indeed socializing in a virtual world, a more 'human' experience than many other online environments" (Erard, 2007). This gives us an idea of leveraging of this social world in terms of language learning and practice.

Currently, one of the many activities taking place in SL is its use as a language learning tool for students who are learning English as a foreign language (EFL). This is because most SL users are communicating in English so EFL learners have the opportunity to communicate both orally and in a written way. Using Second Life as a tool for language learners might be a good idea to enhance learning, interaction, practice etc. and these are going to be discussed in the next section.

\section{Learning English as a foreign language through SL \\ Problem}

Computer technology has an influence on almost everything in human life nowadays; this includes also the domain of education. It has the potential for 
playing a big role in the process of learning a second or foreign language. In recent years, there has been a growing interest in the use of $3 \mathrm{D}$ environments such as virtual worlds in online education. Some classes that demonstrate the diversity of educational activities in SL and that offer core content include cultural anthropology, Spanish, library science, professional development, history, training for emergency personnel, literature, human reproduction, ecology, genetics, educational informatics, English, algebra, toxicology, music, and Japanese culture (Jarmon et al, 2009). Despite its great potential to augment language instruction, very little research has been conducted on the use of SL in the context of EFL learning - specifically in contexts where English is not spoken in everyday life but is often taught in the classroom (Wang, Hongbo, Fangli, \& Qiaoqiao, 2009). Hew and Cheung (2010) summarized the various settings in which past research on virtual worlds had been conducted. They found that a majority of previous studies were carried out in polytechnics and university settings (69\%) and they categorized past research on virtual worlds into eight different disciplines of study including language (e.g. English as a foreign language). One of the least researches done in virtual worlds is language studies $(6.3 \%)$ which support our claim. There have been some initiatives for language learning in SL like LanguageLab (Erard, 2007).

\section{Research}

A very suitable study done by Petrakou (2010) designed an English course in higher education to give the students practice in speaking English in more organized settings. There were seven students in the course and the majority of the students had not previously used a virtual world and these students whose native language is not English were paired up with American students. The students were paired up and the American students had to interview these students for the purposes of their course, the students were given native English-speaking mentors who could acquaint them with the Second Life environment while at the same time providing them with the raw material with which to make presentations during the course. The course schedule included five 2 hours sessions on the virtual campus during which the students had specific tasks to perform and exercises to participate in. The course sessions consisted of a combination of lectures, pair discussions, group discussions and presentations. In addition to this, the sessions included some specific languagerelated practice. Before each session, the students had tasks to prepare, both individually and in groups, which were then delivered orally "in world". The study found that the virtual world provided enhanced interactivity because it allows for synchronous communication and places the student in a spatial dimension. This research gives us enough information about using virtual environment in language learning and practice setting. 

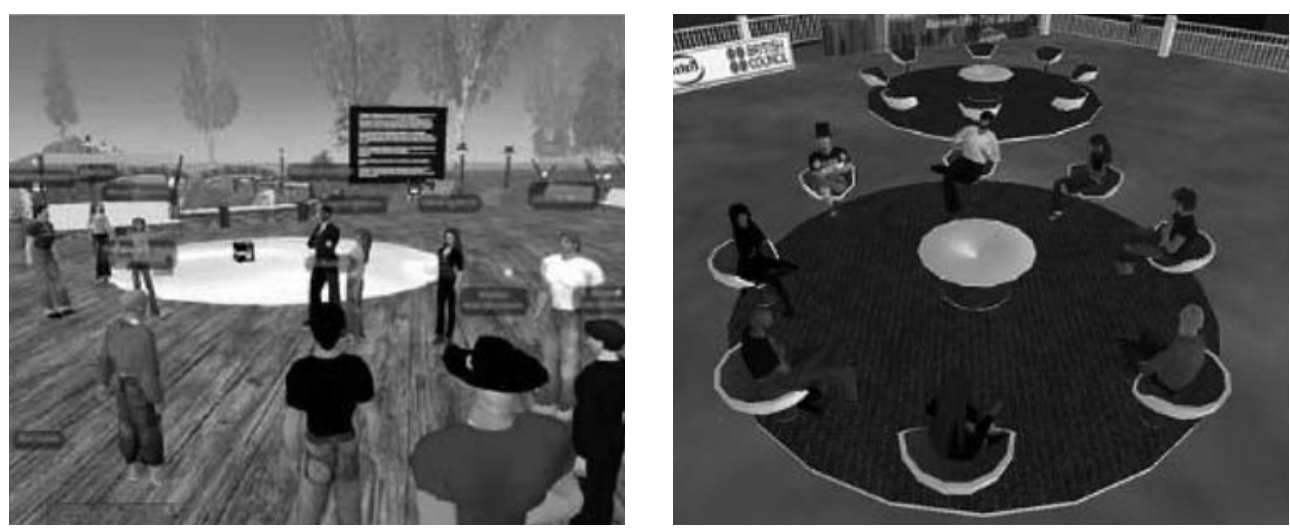

There are some other institutions and private companies using Second Life for language learning or teaching. They use it for their students to meet there and teach some English courses (grammar, reading etc). Besides that one of the main activities in Second Life is for students practicing their English with the students or people who speak English as their native language. This provides language learners to interact with the real native language speakers in a virtual environment. As this is a safe environment for the learn ers, they also prefer talking to the English speakers through this type of tool. In some cases teachers want them to work collaboratively to finish a project together which also helps learners to interact with the other students in the target language.

\section{Advantages and disadvantages of using SL in education/language learning}

Using a virtual world in online education entails both advantages and drawbacks. According to Erard (2007) teaching language in Second Life has an advantage over the other Internet-based methods, such as blogs, podcasts, or text chat, that have overwhelmed foreign-language teachers and been over-utilized in online EFL programs.

The advantages of using SL for especially EFL students might be to access various online communities, interacting with different people from different countries and experience other cultures. SL might serve a good place for them to talk with the native speakers or other language learners especially those who are having hard time to talk with people in English.

Another advantage is that because of the "spatial dimension" of Second Life the use of an avatar, the teacher might be able to visualize important aspects regarding the tone of voice and distance when using English phrases. A good example for this might be, when the teacher tries to describe how the tone of voice is used when saying "excuse me", he also shows the appropriate distance between people with his avatar (Petrakou, 2010). 
In addition to this, in Second Life the learning environment is not only restricted to one place, you can do your activities, experiences and interactions in another place that are a part of the virtual world. Therefore there is no space limitation in Second Life for learning.

As the interaction is essential for language learning, in Second Life it is also very valuable because that's how you interact with the others in SL. Either written or oral, you use SL for interaction with environment and people. Therefore the use of the virtual world might contribute to a collaborative learning activity, which in turn contributes to the socialization and the social interaction among students. So, as an advantage, using Second Life for language learners especially for those who want to practice their communication skills would be precious. Besides, it is a "safe environment" that you can make mistakes and nobody blames you for that, because it is a virtual place and it is free to make mistake anytime.

As for disadvantages misunderstandings might occur during the process and it might affect learning. Actually this might be a big problem for students as they cannot see the mimics and the real body language of the people they are communicating with. Planning and meeting is another problem in synchronous environment, it is needed to be defined very well in order to apply it efficiently.

Technical challenges always occur in these kinds of environments so it is needed to be kept in mind. There might be some internet speed related problems anytime. In Second Life, the students might find it difficult to use voice communication effectively so it needs time. This is because in Second Life, the sound is not the same as in the real world which means that there might be some delays in connection or understanding. Besides that related with sound, in a group of students, if everybody talks at the same time, it will create a challenge for the teacher as well so it needs to be considered. Therefore it might be difficult to distinguish who was speaking and it was also difficult to find a reasonably quiet place for discussions. This might be bad for teacher to understand what is going on in the class and things might get out of the control if it is not designed very well.

Moreover, Second Life provides rich environment in graphics and dynamic setting in terms of social features and even though it may be well suited for synchronous interactivity, but it can be distracting when students wander around the class, walk, click the presentation or fly while everyone focuses the task in the same place. Selecting the appropriate area to study with the students is also important, because it might not be appropriate to study or practice on the mountain or lake especially if there are some distractions.

In addition to those, of course, money matters in SL. You have to buy a land to have space to realize the instruction; therefore, you might need to spend good money on using your own space, buildings, tools, and furniture. There is also rental fee that is needed to be paid, and also there should be ongoing maintenance, editing, and revising process that as an instructor you need to follow. 
Finally as I mentioned before there are both advantages and disadvantages using this kind of virtual environment in instructional or practice purposes especially in language learning. Therefore some suggestions are given in order to mitigate them and to turn to instructional designers' and teachers' pims.
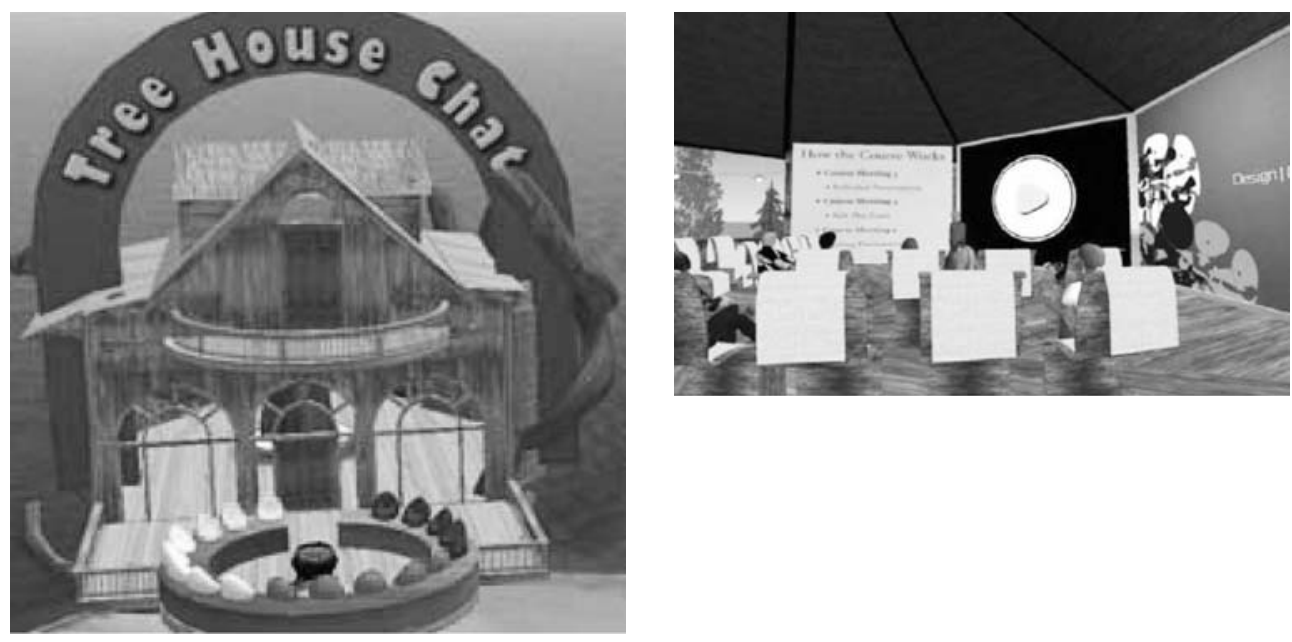

\section{Suggestions}

First of all good design is the most important suggestion for teachers and instructors to leverage this kind of virtual environment. Instructional designer should design each week very well with the underlying theory or theories in order to make it more effective learning environment. There has to be some kind of collaborative activities that learners should do to increase the time that they talk, listen and write in the target language.

Besides, according to Petrakou (2010) and Wang et al (2009) in order to make full use of the virtual environments, the users' technical skills must be improved and the technical problems associated with computer-generated environments must be resolved and tested before in order not to see any difficulty during the learning or practicing process. Giving some information and practice to the students who are going to use this kind of environment would be better before using it. Because the virtual world may be a new environment for the students who are using it, which means that they have to be introduced to a new world with new navigation skills and new means of interaction (oral and written).

One of the most important suggestions is that to support the students' effectively making use of the virtual environment, a website or a blog should be created for that specific course. A blog provides information about the language course and the course website should include all the information about the course, schedules of meetings, the assignments, the assessments etc. In addition to that both might 
support asynchronous interaction and information sharing among the students. Asynchronous interaction is also another important feature since students might want to use other asynchronous tools to continue their interaction which also helps their learning (such as e-mails, blogs or Facebook).

Moreover using different learning tasks in that target language would help learners to experience variable tasks and situations so that they can enhance their learning because using SL might provide them good opportunities to express themselves as it is a kind of virtual but safe environment.

\section{Conclusion}

The paper shows advantages, disadvantages and suggestions with using a virtual world as a context for language learning and practice. Second Life includes not only the virtual environment, but also a diversity of activities, experiences and interactions that are a part of the virtual world. In order to make full use of this enhanced interactivity, the technical challenges must be dealt with and the users' technical skills need to be further developed. While there are many challenges associated with virtual environments such as Second Life, there are tremendous opportunities for learning language or doing practice in English through using this kind of environment.

On the other hand it is also clear that a virtual world is currently not adequate as a learning environment on its own. There is a need to construct an additional information space in order to gather all information regarding the language course and to display the information outside. Furthermore, there is a need to support asynchronous interactivity which might also help students written or another oral interaction (except from virtual environment) with other students in the target language.

This paper was presented in American Educational Communications and Technology Conference (AECT) in 2010, in Anaheim, California, 26-30 October, 2010.

\section{References}

Atkinson, T. (2008). Inside Linden Lab: Second Life [TM] for Educators. TechTrends: Linking Research and Practice to Improve Learning, 52(3), 16-18.

de Freitas, S., \& Veletsianos, G. (2010). Editorial: Crossing boundaries: Learning and teaching in virtual worlds. British Journal of Educational Technology, 41(1), 3-9.

Erard, M. (2007). A Boon to Second Life Language Schools. Retrieved 05/02, 2010, from http://www.technologyreview.com/communications/18510/page1/

Gartner, Inc. (2007). Gartner says 80 percent of active Internet users will have a "Second Life" in the virtual world by the end of 2011. Business Wire. Retrieved April 15, 2010 from

http://www.businesswire.com/portal/site/google/index.jsp?ndmViewId=news_vi ew\&newsId=20070424006287\&newsLang=en. 
Hew, K. F., \& Cheung, W. S. (2010). Use of three-dimensional (3-D) immersive virtual worlds in K-12 and higher education settings: A review of the research. British Journal of Educational Technology, 41(1), 33-55.

Jarmon, L., Traphagan, T., Mayrath, M., \& Trivedi, A. (2009). Virtual world teaching, experiential learning, and assessment: An interdisciplinary communication course in second life. Computers \& Education, 53(1), 169-182. doi: DOI: 10.1016/j.compedu.2009.01.010

Kalyuga, S. (2007). Enhancing instructional efficiency of interactive e-learning environments: A cognitive load perspective. Educational Psychology Review, 19(3), 387-399.

Linden Research, I. (2010). Second Life (Version 1.23.5).

Petrakou, A. (2010). Interacting through avatars: Virtual worlds as a context for online education. Computers \& Education, 54(4), 1020-1027. doi: DOI: 10.1016/j.compedu.2009.10.007

Twining, P. (2009). Exploring the educational potential of virtual worlds- Some reflections from the SPP. British Journal of Educational Technology, 40(3), 496-514.

Wang, C. X., Hongbo, S., Fangli, X., \& Qiaoqiao, Y. (2009). Integrating Second Life into an EFL Program: Students' Perspectives. Journal of Educational Technology Development \& Exchange, 2(1), 1-16. 